\title{
Hermeneutics of Earning Management: Between Pressure and Opportunity
}

\author{
Murniati *) \\ Mahmudatus Sa'diyah **) \\ Subadriyah $* * *)$
}

\begin{abstract}
The purpose of this study was to find out and understand the informants which included internal auditors and staff on the practice of earnings management carried out by managers of savings and loan cooperatives (KSP). This research was conducted at A and B savings and loan cooperatives in Jepara. Cooperatives are chosen with very high NPLs and those with NPLs below the standard. Research informants were chosen purposively based on individuals who have been long enough and intensively integrated into their fields of work. The analysis in this study is an interpretive or hermeneutic approach. The way this approach works is by interpreting the language through grammatical and psychological interpretation. The results obtained show different information in earnings management practices. Opportunities in utilizing the application of generally accepted accounting principles are the things that underlie earnings management. The informant stated that earnings management could not be considered as profit manipulation as long as the process is carried out in the notification of accounting standards. The accounting staff said his opinion that earnings management behavior could not be considered as corrupt unless the behavior was not carried out in accounting standards.
\end{abstract}

Keywords: Accrual Accounting; Earnings Management; Opportunity; Pressure

\section{INTRODUCTION}

\subsection{Research Background}

Today's business transactions are increasingly complex. The parties that have concerns in the company, having a right to know the company's operations. For this reason, companies must report that into a form of financial statements. The financial reports provide information relating to company operations, especially financial information to outside parties. So, a financial report must have an Accounting Standard so that it can be understood by all parties. At present, in preparing financial statements, especially in profit-oriented organizations, they prefer to use accrual basis. Accrual basis is considered more rational and fairer in terms of reflecting the real financial condition of the company. Also, the accrual basis is also able to provide flexibility to the management in determining the choice of accounting method, as long as it does not deviate from the rules of the applicable Financial Accounting Standards. If the method of accounting by management is doing purposely and has a specific purpose, it called earnings management.

In general, the accounting profit rate is always different from cash income. But if accounting earnings are found is the same as the cash income, it is only a coincidence (Riduwan, 2012). That was what encourages managers to take earnings management actions. Because the number of accounting profits is difficult to trace into net cash inflows. Earnings management actions result in financial information being blurred, and financial statement users find it difficult to determine the quality of financial statements. The practice of earnings management is believed to arise as a direct result of the efforts of the managers or compilers of financial statements by regulating the number of profit figures, for personal gain or the interests of the company. Riduwan (2012) states that earnings management actions arise because some motivations are based on debt covenants, bonus 
plans, and political costs. Debt covenant is carried out by managers to minimize violations of debt agreements that may occur between companies and creditors. Bonus plan motivates managers to achieve targeted performance by adjusting the number of profit figures. This arranged so that the bonus that has been prepared by the company for the manager who reaches the target can be achieved whereas political costs are carried out to minimize the political costs incurred due to the existence of laws and regulations which constitute government intervention.

Earnings management research has been carried out, but most still use quantitative methods, without regard to the interpretation of the true meaning of earnings management practices. For this reason, based on the description above, this study intends to study forms of interpretation or meaning as true conditionals from earnings management practices in savings and loan cooperatives. In the process of interpretation, the researcher will be guided by vorurteil that defined by several experiences and a set of knowledge. Researchers try to find the nature of a text or reality in the context of the answers given to the meaning of an earnings management (based on hermeneutical studies). In this case, the researcher conducted a dialectical method with the finance department staff and internal auditors by throwing questions and giving answers to each of the two KSPs in Jepara.

\subsection{Research Problem}

Based on the background described above, the formulation of the problems in this study is what is the true meaning of management practices in cooperatives? And what are the reasons for earnings management in cooperative operations?

\subsection{Research Purpose}

a) To find out the true meaning of earnings management practices in cooperatives

b) To find out the reason for doing profit management in cooperative operations

\section{THEORETICAL FRAMEWORK}

There are several previous studies that are used as references in this study, Riduwan (2012) examines reality in the mirror cracking of accounting profits in the frame of interpreting nonaccountant practitioners with a hermeneutic study approach, the results of his research show that in the frame of interpretation of non-accountant business practitioners, reality which is represented by an unclear accounting profit symbol. Also, Riduwan (2010) also examines ethics, and corrupt behavior in earnings management practices, from his research, obtained an understanding that informants have different opinions and behaviors on earnings management practices. They argue that the practice of earnings management is always carried out systematically based on certain motivations and interests. Faridah (2016) examines the application of management to boarding school cooperatives, the results of his research show that cooperative management is good enough in implementing its management system and has implemented the principle of the family in its organizational culture.

\subsection{Hermeneutics Study}

The philosophy method of hermeneutic is the activity of thought that interprets and understands the meaning of a text (reality) rationally to search and find the results. Hermeneutics as a system of interpretation that defines three things, first, expressing one's thoughts in words, acting as interpreters and translating. Second, the effort to divert a language whose meaning is not known to the reader in another language that can be understood by the reader. The last one is the movement of unclear expressions of thoughts which are transformed into clear expressions of mind 
(Puspinanti, 2015). Putra (2012) revealed that in the process of interpretation, the interpreter is guided by vorurteil (prejudice) that defined by several experiences and a set of knowledge. With his experience and knowledge, the interpreter seeks an essence in the text and reality in the context of history and tradition when the text or reality is born.

\subsection{Profit Management}

The earnings management means a practical action taken by managers to influence earnings figures. In different perspectives and arguments, there are several parties who express opinions differently. One party said that earnings management is not an act of manipulating profits if it is still done in the corridor of generally accepted accounting principles. While on the other hand profit management is a form of profit manipulation because earnings management is always based on the motivation to obtain personal benefits by describing the company's performance improperly (Riduwan, 2010). This earnings management is believed to emerge as a direct result of the efforts of the managers or compilers of financial statements to regulate the number of profit figures for personal or corporate interests. The practice of earnings management is based on motivation and interests and is also motivated by certain economic factors. The basis of managers for earnings management is based on the motivation of political costs, bonus plans, and debt covenants. To achieve targeted performance, managers are motivated to set the number of profit figures about the bonus that will be obtained. Strategies that can be implemented by managers in earnings management practices include making a choice of accounting methods and making certain estimates as accounting policies.

\section{RESEARCH METHOD}

\subsection{Research Design}

Qualitative approach as an approach in this study. The qualitative approach used is the Hermeneutic Study or interpretive approach. What do informants understand about earnings management practices? What is the practice of earnings management in view and responded to by informants? The answers to these questions are a problem related to the meaning of "text". Every meaning of "text" requires an effort for interpretation and interpretation that aims to gain an understanding of the "text" concerned.

The attempt to interpret the text to gain understanding according to Findling (2007) is referred to as hermeneutics. According to Bungin (2011), a simple way of hermeneutics is a method of interpreting language. This is through grammatical interpretation and psychological interpretation. Grammatical is how a person speaks a language, where he talks and how he speaks while psychological interpretation is what can be captured from the meaning contained in each discussion.

\subsection{Research Informants}

The research subjects who took were financial staff and internal auditors from KSP in Jepara. The cooperative was used as a place of research, namely: A and B Savings and Loan Cooperatives in Jepara. Subjects are chosen purposively based on individuals who have been long enough and intensively integrated into their fields of work. The subject of the study was used as the main informant or main data source. Interviews were conducted in Jepara.

The financial section staff was chosen as the subject / informant in the study because the finance department staff were considered to know the process of preparing financial statements. So that all kinds of recording processes to deliver financial statements, this section knows that. Next is the internal auditor; this subject was chosen as an informant because of his responsibilities and 
expertise in ensuring that the financial statements and the preparation process were by existing standards and procedures.

Table 1 Research Informants

\begin{tabular}{|c|c|}
\hline The Informant Identity & Work \\
\hline Tri & Financial Staff at KSP A \\
\hline Zahro & Finance Staff at KSP B \\
\hline Diyah & Internal Auditor at KSP A \\
\hline Hidayat & Internal Auditor at KSP B \\
\hline
\end{tabular}

Source: Primary Data Processed, 2018

The object of research studied or aspects that become a reality in the research is about the meaning of earnings management practices in savings and loan cooperatives. The first object of research is the Savings and Loan Cooperative A (KSP A). KSP is located in Jepara and was established in 2008. Members of this cooperative consist of employees from foundations in Jepara. This KSP management has never changed since it found until 2013. In 2012 there was a change in management and managers because at the 2011 Annual Member Meeting (RAT) held in March 2012. These changes were made after one of the members asked for a difference significant depreciation due to changes in the filing of the useful life of fixed assets. Based on these findings, then the members want to revamp the report in the coming period. However, in the following year RAT, which was held in March 2013, there was still no change, so the members wanted a change of management and manager. Also, members want the existence of continuous audit reports. Since 2013 until the end of 2017, this KSP manager has changed three times. This KSP has assets of 3.7 billion until 2017. However, this KSP experiences bad loans of up to 29\%. This is very high when compared to the standard provisions, namely for cooperatives is $10 \%$.

The second object of research is KSP B. KSP was founded in 2013. Like the first research object, KSP is also composed of employees from a foundation in Jepara. This KSP has grown rapidly since its establishment until the end of 2017, two branch offices have been established. KSP has as much as 6.7 billion at the end of 2017. The cooperative's bad credit is very much different from the bad credit of KSP A, this KSP B's Non-performing Loan (NPL) is still in the range of standard bad loans for cooperatives, that's $3.6 \%$.

\subsection{Research Framework}

Hermeneutics Study $\rightarrow$ Internal Auditor and Accounting Staff $\rightarrow$ Profit Management Practices

Picture 1 Research Framework

\section{RESEARCH RESULT AND ANALYSIS}

\subsection{Profit Management an Opportunity}

Accrual recording basis provides opportunities for managers to be able to take earnings management actions. Accounting practices, especially accounting-oriented profit organizations today use the basis of accrual accounting. Accrual accounting is not only recording transitions in the period in which cash has been received or paid by the company. However, accrual accounting seeks to record all financial effects of events and circumstances that have cash consequences for equity in the period in which the transaction occurred (FASB 1991, SFAC 6, Paragraph 139). 
Accrual accounting also takes into account deferrals, not only accruals, including allocation and amortization (FASB 1991, SFAC 6, Paragraph 141).

In accrual accounting, the procedures of using deferrals, accruals, and allocations and amortization is to recognize and report income, profits, expenses, and losses for a certain period as a reflection of the company's performance in a certain period. During submitting a performance report, the company continues to carry out its business activities without being known when it will stop. Accrual accounting is used to overcome problems related to timing (when) the recognition of cash flow which is sometimes not in line / together with the timing of an activity completed so that the increase and decrease in assets and liabilities and recognition of income, costs, profits, and losses can be displayed in full of assessing the company's performance in the current period.

Procedures for accruals and deferrals, obscuring information about cash flow. This is a weakness of accrual accounting (Subramanyam \& Wild, 2009). Weaknesses in accrual accounting and supported by the existence of information asymmetry between outsiders and managers, are often used by managers in making earnings management actions. In this case, the manager is the manager of a company that has a lot of information when compared to parties outside the company. Other companies may not monitor every manager's behavior and the manager's decisions in detail (Healy \& Palepu, 1993; Eisenhardt, 1989).

Earnings management is interpreted differently by several authors. Schroeder \& Clark (1998) interpret earnings management as a management effort to influence the net income currently reported. In addition, Fischer \& Rosenzweig (1995) interpret earnings management as the actions of managers who aim to enlarge and minimize the net income that is being reported without any increase or decrease in the company's economic profitability in the long run. This definition illustrates that actually, earnings management, in the long run, does not affect profitability or total profits. This is because earnings management is carried out by managers by shifting the reporting period of profit alone through minimizing or increasing the profits that are currently recognized.

However, Schipper (1989) has a different definition from Fischer \& Rosenzweig (1995), earnings management is defined as an action carried out intentionally in the process of preparing financial statements with the aim of gaining personal and/or organizational benefits. Likewise, Healy \& Wahlen (1999) say that earnings management is carried out by managers by using their decisions when recording transactions to change, with the aim of giving a wrong picture to stakeholders about the company's economic performance and to influence contractual outcomes that depend on numbers accounting terms reported.

The last definition shows that earnings management does not only shift the period of recognition of profits but leads to the efforts of managers to give a wrong picture to stakeholders about the company's performance so that stakeholders make economic decisions by the expectations of managers. The practice of earnings management by managers shows the existence of opportunistic behavior (Scott, 2000). This is because the practice of earnings management is being motivated with certain interests and economic factors. These interests are in the form of company interests and the manager's interests. Scott (2000) explains that managers have the motivation to do earnings management based on debt covenants, bonus plans, and political costs. This means that the existence of earnings management practices is due to motivation and interests like pressure of affiliated parties, altruistic, minimization of financial costs, manager wealth maximization, earnings management motivation, political costs minimization, speculative motivation (Hamid, Hashim, Salleh, 2012, Kang Young Lee \& Griffin, 2014; Neifar, Halioui, \& Abdelaziz, 2016).

While Watts \& Zimmerman (1986) classify earnings management motivation into four, each of them is motivation to avoid debt covenant violations, motivation to get bonuses and other compensation, influence the decisions of capital market players and avoid political costs. The 
motivations underlying earnings management can be classified into three groups, namely capital market motivation, contract motivation, and motivational regulation. More broadly Setiawati \& Na'im (2000) explain that the importance and motivation of earnings management is motivation to fulfil the agreement of accounting numbers in debt contracts, motivation to be able to achieve management compensation associated with accounting profits, motivation to influence stock prices in the capital market, consideration of tax payments, motivation to obtain or maintain control of a company, consideration of competing companies, and consideration of employees.

The earnings management pattern that is often carried out by managers is the pattern of increasing profits (income increasing), income smoothing and income decreasing (Dechow \& Skinner, 2000). The pattern of earnings management is achieved through appropriate spending strategies, selection of operating decisions, and investments (McNichols and Wilson 1988), and the selection of accounting techniques that can be considered strategic (Schroeder \& Clark, 1998). Operations, spending, and investment decisions are not often producing results as expected by the manager even though the decision is considered to be optimum.

For this reason, managers turn to be able to focus their attention by choosing accounting techniques that are considered to be the most effective in influencing earnings figures (Teoh, Welch, \& Wong, 1998). The operationalization of earnings figures that utilize this accounting technique is through changes in accounting policies, through accruals management, and earlier application of new accounting standards (Ayres, 1994).

The practice of earnings management carried out through accrual management is driven by inherent weaknesses in accrual accounting and the flexibility in calculating earnings figures. This flexibility arises because of the many choices of accounting methods, so that management can record certain facts differently, besides allowing subjectivity or judgment in determining the estimation of financial report preparation (Djakman 2003).

Accounting techniques chosen and implemented by management can be carried out freely because there are no restrictions and are still in the corridor of general acceptable accounting principles (PABU). For this reason, earnings management carried out through the use of accrual accounting techniques is permitted. In contrast to earnings manipulation, it is a violation of the GAAP in producing the company's financial performance in accordance with the interests of managers or companies (Djakman, 2003). Similarly, Schroeder \& Clark (1998) give their opinion that earnings management is based on managerial considerations or through the selection of accounting methods and procedures within the limits permitted by accounting standards, earnings management is not a fraud, even though earnings management in these ways can influence stakeholders' decisions. However, it does not rule out the possibility that earnings management practices can lead to fraud.

Thus, it can be interpreted that the practice of earnings management carried out by KSP, in this case, is the manager, due to the existence of opportunities that exist in the interest of the shareholders/members of the cooperative itself. In the context of the understanding given by Fischer \& Rosenzweig (1994), the practice of earnings management is merely an attempt to "play around" profit figures on paper and not cause material losses to anyone. This profit figure game is carried out by managers by utilizing the flexibility of available accounting standards. This happens because accounting standards provide sufficient opportunities for managers to record certain facts in different ways and have the opportunity to use subjectivity in making accounting estimates.

Accounting staff and internal auditors have the same opinion and view, that accrual-based accounting can provide better information about company performance than cash-based accounting. The following are their statements: 
Current accounting is operationalized by using accrual principles that recognize assets, income and expenses, and liabilities, regardless of whether the related cash has been received or paid. This makes accounting can provide financial information better when compared to cash-based accounting. [Diyah - internal auditor]. In my opinion, to recognize and report income and expenses on an accrual basis is indeed better in describing the performance of company managers. Acceptance of each expenditure is only the effect of the manager's performance, not the performance of the manager himself. [Hidayat - internal auditor]. Accrual-basis is considered better than cash-basis if it is used to measure and assess the manager's operating performance of a company. For example, for example, last month I became a manager and could sell products on credit of IDR 10,000, the fees I had paid in cash were IDR 8,000. This month you replaced me as a manager. This month you cannot afford to sell any of these products and do not pay any fees, but you can collect the credit sales of Rp 10,000 last month. Which is better, my performance last month or your performance this month? [Zahro - accounting staff].

\subsection{A Pressure Profit Management}

Management, in this case, is expected to provide benefits to shareholders. Management seeks to reduce the company's risk to meet the interests of shareholders so that earnings management actions must be carried out (Wang, 1994). Stability in achieving company profits provides benefits for shareholders in profit sharing.

On the other hand, empirical studies show markets prefer stable earnings. The market considers that the average profit rate is considered to have a low risk compared to the fluctuating profit figures (Putra, 2010). Management is expected to be able to keep profits stable so that stock prices remain stable as well. Fluctuating company operations result in fluctuating stock prices as well. Especially for companies that are conducting an IPO, fluctuating profits will hurt the company because they risk the shares not selling or less attractive.

The company has an interest in the survival of the business. Besides companies, external parties such as shareholders also have an interest in the companies survive. Such conditions require companies to continue to provide a stable profit so that stock prices remain stable as well. Furthermore, it is expected that the company will survive and continue to grow.

In the context of the bonus program, Scott (2000) provides an example of how strategies and patterns of earnings management are carried out. Managers who are facing a bonus program related to profit targets, are likely to be involved in various patterns and earnings management strategies such as the following: 1) taking a bath, namely the act of shifting the cost of discretionary accruals in the next period to the current period or shifting discretionary accruals earnings from current period to the next period; (2) minimizes profits when profits before accrual decisions are smaller than the lower limit or exceeds the upper limit of profits; (3) maximize profit when earnings before accrual decisions exceed the lower limit but do not exceed the upper limit of profits, and (4) income smoothing. Although the pattern and strategy of earnings management above are related to management motivation in dealing with bonus programs, the pattern and strategy can also be applied in the context of motivation and other management interests.

These auditors agree that the manager's performance is evaluated based on the company's ability to generate cash, but the cash flow is not a measure for their performance that evaluates which is limited by the accounting period. Diyah (internal auditor) asserts that if the manager's reported profits are exactly same as the amount of net cash received, that is just a coincidence.

The informants agreed that accrual accounting is far better than accounting which only records cash receipts and expenses. They realize that accounting is basically just focusing on recording and reporting transactions that have consequences on cash. However, because cash flow 
is not always concurrent with the completion of a transaction, it is operationalized with the accrual accounting concept. Nevertheless, they have the opinion that the application of accrual accounting should be limited to real business events and can be tested for truth. According to Hidayat (internal auditor), accrual accounting applied to a non-real transaction can obscure the cash flow of the reported transaction. He argues that the accrual principle in calculating profits is set for real events; therefore accounting earnings can be easily understood. However, at present, the accrual basis is also often applied to events that are not real and events that are not according to facts. This causes accounting earnings to be difficult to understand. As a result of the accrual basis that is applied to events that are not real, it makes the flow of money become vague and difficult to interpret. The objectivity of accounting earnings still needs to be questioned: what is the fact for the money flows?

Agreeing with Hidayat (internal auditor), Zahro (accounting staff) said that in accounting practices there are events that are actually just concepts but have been recorded as real events, so accounting profits do not show financial performance that is easily understood operationally by ordinary people. Actually, in describing financial performance, accrual accounting is very good. However, if it is applied beyond the money flow limit reflected in the profit rate, it becomes unclear.

The impact that can be generated from accrual accounting that blurs cash flow and the company's ability to generate cash is also experienced by Tri (accounting staff). Tri stated that if accrual accounting is used for conceptual events that are not real, then the cash flow that actually wants to be represented by recording and also reporting income becomes unclear. He added: Laws and tax regulations do not fully adhere to the concept of accrual accounting applied in accounting. I think we all understand that the concept of financial accounting and the concept of tax accounting are different where financial accounting emphasizes more on the part of economic substance than its legal form, tax accounting favored both. In addition to the economic substance, the legal aspects of income and costs are important in terms of taxation. Cash flow on income and costs in taxation must be clear and arise from a real transaction, not just a concept.

According to Tri, the clarity of the cash flow on income and costs is closely related to the certainty of the amount of tax that must be paid by the taxpayer. The tax payable is the amount that must be paid instead of the conceptual amount. "Therefore, the accrual principle is only applied to real transactions and events in tax accounting," Tri said.

For accountants, the term earnings management is often a frequently used term. Educator accountants, management accountants, and public accountants are very familiar with this term. However, the expectations of each accountant vary according to the background of the work or profession they are living. Likewise, for accountants or financial departments in savings and loan cooperatives. Interpretation of earnings management by accountants in savings and loan cooperatives is formed by thinking about the structure of earnings formation in financial statements, namely profits occur from reducing income with expenses.

Referring to various existing literature, for example Schipper (1989), earnings management is a very deliberate intervention in the external financial reporting process with the intention of gaining personal benefits. Diyah (KSP A internal auditor) and Hidayat (KSP B internal auditor) interpret earnings management exactly as understood by Schipper (1989: 94).

Earnings management is a deliberate intervention carried out by managers to influence the amount of profit, "said Diyah. "Several times, I encountered a condition of recording that was not fair. Where there is a change in the useful life of fixed assets from previous years, this is done so that the depreciation value becomes smaller and then profits increase ", he continued.

Meanwhile, Hidayat said that based on the literature I read, earnings management is carried out by managers and managers of cooperatives to convey the profit figures according to their 
wishes. Earnings management, by itself, is done through income management and cost management.

Likewise, the interpretation given by accounting staff, namely Tri of KSP A and Zahro of KSP B. Tri interpreted earnings management as a manager's effort to influence earnings figures, he said that such practices are requested by managers because there are certain interests. Managers and administrators want some adjustments in the recording process, especially at the end of the year.

Based on his experience as an accounting staff member, he simply said that from the various books that I have read about earnings management it is true, not only in theory but indeed that is what happens in practice. Apart from that, I also often read the writing of the results of the research and it was true. The profit figure can indeed be arranged according to your wishes. Its interests are various, among others, to fulfil the requirements in disbursing bank credit ceiling in an effort to obtain a substantial annual bonus, as an effort of managers and administrators so that members of the cooperative continue to believe and maintain their position when RATs can be as an effort to reduce the amount of tax paid.

The statements of the informants show that the earnings management carried out by managers is always based on motivations and certain interests. This is consistent with Scott's statement (2000: 180) that the practice of earnings management arises because of the manager's opportunistic behavior.

As explained earlier, Djakman (2003) revealed that earnings management carried out through accrual management is not as same as earnings manipulation. Earnings management is carried out by utilizing the inherent weaknesses of an accrual accounting policy and is still in the corridor of generally accepted accounting principles. While earnings manipulation is an action that violates the generally accepted accounting principles to produce a company's financial performance that is by the interests of managers and the interests of the company (see also Schroeder \& Clark, 1998). Internal auditors and accounting staff of KSP A and KSP B agree with Djakman (2003) and Schroeder \& Clark (1998). The following are the comments they gave:

The practice of earnings management is considered valid if carried out under financial accounting standards. Managers and accountants cannot be blamed by that because earnings management in such a manner is not fraudulent. However, earnings management can turn into fraudulent deeds if there is intentional managers or accountants who violate accounting standards for example in the form of data manipulation, calculation and reporting. [Hidayat-Internal Auditor].

Through accrual accounting, earnings management basically can affect earnings figures on paper by utilizing flexible accounting rules. If everything is done without violating accounting rules, what is wrong with earnings management? Choosing suitable accounting techniques is a management right, while accounting rules do allow it. [Diyah - Internal Auditor].

To influence the rate of profit with the accounting method is not an act of fraud so that the practice of earnings management in a manner like this can be done. Let alone just choosing an accounting method to shift transactions that affect income and costs alone is not a violation as long as the recording and reporting are consistent and do not violate accounting standards. Financial performance is affected short-term if accrual management is within limits permitted by accounting standards, while for long-term corporate performance reflected in earnings figures are the same as if the profit figures were not affected. [Tri-accounting staff].

The informant's view above shows that in the informant's perspective, the practice of earnings management is not corrupt behavior if carried out in the corridors of accounting standards. This is because accounting standards are seen as rules that are believed not to produce misleading information for users of financial statements. The accountant's view that earnings management is not an act of fraud is also inseparable from their understanding of the meaning of "fraud" in a frame 
of their profession, especially those contained in the Audit Standard Section 316 (IAI 2001) below: Fraud is different from mistakes. The factors that distinguish it are whether the underlying actions that result in misstatements in the financial statements, both in the form of intentional and unintentional actions. Fraud in financial reporting in the form of intentional omission of the amount or disclosure of financial statements fooling users of financial statements involving manipulation, changes in accounting records, forgery including intentional misappropriation of accounting principles relating to the amount, method of presentation, method of disclosure and classification .

From a different perspective, it is interesting to look at the views on earnings management practices by Diyah (internal auditor). Diyah understands that earnings management is a deliberate intervention by managers or accountants in an external financial reporting process that has the purpose of gaining personal benefits. Although earnings management is carried out through accrual management strategies or real operations management that do not violate accounting standards. he disagrees with the opinions of accountants who say that the practice of earnings management is not corrupt behavior. He stated that carried out through any strategy by violating accounting standards or not the practice of earnings management was corrupt. I say corrupt action because it is based on motivation and personal interests by overriding the interests of other parties. The existence of earnings management actions causes the financial statement numbers to be affected and in favor of the manager's interests. The purpose of the practice is clear, that is, expect financial report readers to be targeted by earnings management practices to make decisions that benefit managers or companies. This is detrimental to the other party.

Diyah's opinion is very consistent with IAI's (2015) statement in KDPPLK paragraph 16 relating to the neutrality of financial statements, and PSAK No.1 (Revised 2015) paragraph 5 relating to the purposes and objectives of the following financial statements:

Information must be directed at the general needs of users and does not depend on the needs and desires of certain parties. There should be no business that only benefits some parties from presenting information, while it can harm other people who have opposing interests. [KDPPLK paragraph 16 italics added as an emphasis] The general purpose of financial statements is to provide information about the financial position, cash flow and company performance that can be useful for users of financial statements to make an economic decision and show management accountability for the use of resources entrusted to them. [PSAK No.1 Rev.1998 paragraph 5 italics added as an emphasis]

Diyah stated that there was no earnings management carried out without motivation and interests, both personal interests and interests of a company. "To achieve this interest, earnings management must be done intentionally and systematically," he said. Diyah then continues the sentence. Based on normal thinking, the selection of accounting methods should be carried out without motivation and certain interests that provide superior benefits to one party than the other. The choice of accounting method should also be without going through a systematic study by considering the impact on the rate of profit because any accounting method will produce the same rate of profit in the long run. Because the mind of the manager and the accountant is more focused in the form of displaying his profit numbers rather than the substance, then the practice of earnings management is considered a matter of course.

Furthermore, Diyah revealed that the practice of earnings management includes corrupt behavior that is driven by corrupt thoughts. "I simply define a corrupted mind as a thought that is not wrong with something that is wrong or thinks it is not evil towards something that is evil," explained Diyah. According to him, such thoughts arise because the legal aspects take precedence over the nature of an action and its impact. He also stated that in my view the practice of earnings management is not an act of fraud if it is done without violating accounting standards, is a statement 
based on reason and thoughts that deviate from reason and normal thoughts. The thought was corrupted by consideration of legal and regulatory aspects, namely accounting standards. The practice of earnings management does not rig accounting standards when viewed from the legal aspect, but rigging the interests of other parties by making accounting choices systematically.

Diyah's opinion seems to be very inspired by the criticisms of Kwik KianGie on the corruption phenomenon written in his book. Kian-Gie (2006) stated his criticism of acts of corruption. Corruption thoughts are indeed difficult to see from actions but are easily seen from motivation. It is not possible for all crimes starting from bad faith can be anticipated and arranged very completely by the sentence in any precise legislation. The reason is the power of innovation and unlimited human creative power in finding ways and formulating words that state that they have committed no crime. (P. 44) Corruption in the sense of being a corrupted mind that does not steal state money is no less dangerous than corruption. Corrupted thought flow also results in extraordinary losses. (P. 48)

As an internal auditor, Diyah said that earnings management practices are unacceptable behavior. This is because earnings management can cause a loss of credibility of financial statements and increase information bias in financial statements. So that this can disturb the users of financial statements in believing the engineered profit figures as profit figures without engineering. "With earnings management, users of financial statements, for example, investors do not receive accurate information about profits in order to evaluate the results and risks of their investment portfolios," said Diyah.

The results of the research that has been conducted show the results that the proportion of earnings management actions is mostly carried out in savings and loan cooperatives. This is emphasized by the motivation of managers to achieve targeted performance and to minimize violations of debt agreements and opportunities that exist in the interests of shareholders and the interests of the members themselves. Most managers carry out earnings management through strategies for selecting accounting methods and determining accounting estimates. Only a small portion is made through real legitimate transactions. This earnings management action still contains controversial understanding, where on the one hand it is always underestimated and tends to be misleading. However, on the other hand, this action is not fraud if carried out in accordance with accounting principles.

Earnings management is seen as an estimation of profits to avoid negative reactions from investors or users of financial statements. In addition, it is also used to protect yourself and the company in anticipating unexpected events for the benefit of the parties involved in the contract. This study contributes theoretically and practically to the concept of earnings management in cooperatives and can also be used as a discourse by users of financial statements in making decisions. From the creditor side, it can help in analyzing credit and earnings management practices so that creditors can make good decisions regarding creditworthiness.

\subsection{Research Proportion}

$\mathrm{P}_{1}$ : Accrual accounting is believed to be one of the reasons for managers to practice earning management.

$\mathrm{P}_{2}$ : Earning management is motivated by certain interest and economic factors. These interest are in the form of company interest and manager personal interest.

$\mathrm{P}_{3}$ : The practice of earning management through accrual management driven by inherent weakness in accrual accounting and flexibility in calculating earning figures.

$\mathrm{P}_{4}$ : The size of the bonus is a key consideration in encouraging earnings management practices. 


\section{RESEARCH CONCLUSION AND LIMITATION}

\subsection{Conclusion}

Accrual is an important concept that is used as an underlying assumption in accounting practices. Although the accrual concept itself is an imperfect concept and brings weaknesses. The imperfections and weaknesses inherent in accrual accounting are often used by managers to conduct earnings management with the intention of achieving certain goals. The interests of other parties, both shareholders and stake holders, are very important for savings and loan cooperatives in particular, and organizations in general for the survival of the organization. These interests force organizations to take earnings management actions but remain in the context of GAAP without breaking the rules or earning manipulation. Thus, can the practice of earnings management be equated with the practice of earnings manipulation? Is earnings management a reflection of corrupt behavior? The answers to these questions are still controversial, according to the perspective of each research informant. Accounting staff assess that earnings management is not the same as earnings manipulation. And also, not corruptive actions as long as they are within the frame of accounting standards. Meanwhile, internal auditors say that the practice of earnings management is an unacceptable behavior. However, earnings management can cause loss of credibility of financial statements and increase information bias in financial statements. This can disrupt financial report users who believe in the engineering profit figures as profit figures without engineering. Even though it is still in the corridor of the standard of action, this provides an opportunity for managers to be able to take actions that lead to corrupt actions.

\subsection{Limitation}

The implementation and results of this study contain several limitations. The first limitation is that this study only seeks to understand the opinions and attitudes of informants on earnings management practices carried out by managers in accordance with their respective positions and professions, and do not try to express their opinions more about what should be done in accounting management practices profit does not occur. Second, in this study the opinions and attitudes of informants on earnings management practices have not been generalized as interpretations of accountants and business people as a whole. Further research on different informants is still very necessary.

\section{REFERENCES}

Ayres, F. L. (1994). Perception of Earnings Quality: What Managers Need to Know?. Management Accounting Research, 7(9), 27-30.

Bungin, B. (2011). Analisis Data Penelitian Kualitatif : Pemahaman Filosofis dan Metodologis ke Arah penguasaan Model Aplikasi. Jakarta: Raja Grafindo Persada.

Dechow, P., \& Skinner, D.. (2000). Earnings Management: Reconciling the Views of Accounting Academics, Practitioners, and Regulators. Accounting Horizons, 14, 235-250. https://doi.org/10.2308/acch.2000.14.2.235.

Djakman, C. D. (2003). Manajemen Laba dan Pengaruh Kebijakan Multi Papan Bursa Efek Jakarta. Makalah Simposium Nasional Akuntansi VI. Surabaya, 16-17 Oktober 2003: 141162.

Eisenhardt, K. M. (1989). Agency Theory: An Assesment and Review. Academy of Management Review, 14(1), 57-74. https://doi.org/10.2307/258191. 
Faridah, I. (2016). Penerapan Manajemen pada Koperasi Pondok Pesantren Al-Amanah Al Gontory Parigi Baru Pondok Aren Kota Tangerang Selatan. Skripsi. Fakultas Ilmu Dakwah dan Ilmu Komunikasi, UIN Syarif Hidayatullah Jakarta.

FASB. (1991). Statement of Financial Accounting Concepts. Illinois: Irwin.

Findling, J. (2007). Speaking of Language: On The Future of Hermeneutics. Research in Phenomenology, 37(2), 271-284. http://dx.doi.org/10.1163/156916407X185692.

Fischer, M., \& Rosenzweig, K. (1995). Attitude of Students and Accounting Practitioners Concerning The Ethical Acceptability of Earnings Management. Journal of Business Ethics, 14(6), 433-444. https://doi.org/10.1007/BF00872085.

Hamid, F., Hashim, H. A., \& Salleh, Z. (2012). Motivation for Earnings Management Among Auditors in Malaysia. Procedia - Social and Behavioral Sciences, 65(3), 239-246. https://doi.org/10.1016/j.sbspro.2012.11.117.

Healy, P. M., \& Palepu, K. G. (1993). The Effect of Firms Financial Disclosure Strategies on Stock Prices. Accounting Horizon, 7(1), 1-11.

Healy, P., \& Wahlen, J. M. (1999). “A Review of The Earnings Management Literature and Its Implications for Standard Setting". Accounting Horizons, 13, 365-383. https://doi.org/10.2308/acch.1999.13.4.365.

Kang Young Lee, R. M., \& Griffin, T.. (2014). Motivational Factors Affecting Earnings Management of Not-for-profit Hospitals in South Korea. Research Journal of Business Management, 8, 1-27. https://doi.org/10.3923/rjbm.2014.1.27.

Kian-Gie, K. (2006). Pikiran Yang Terkorupsi. Jakarta: Penerbit Buku Kompas.

McNichols, M., \& Wilson, G.P. (1988). Evidence of Earnings Management from the provision for Bad Debts. Journal of Accounting Research, 26, 1-31. https://doi.org/ 10.2307/2491176.

Puspinanti, A. (2015). Studi Hermeneutika Interpretasi Inspektorat Atas Laporan Keuangan Pemerintah Daerah (Studi Kasus Pada Inspektorat Provinsi XYZ). Tesis, Program Magister Akuntansi Universutas Hasanuddin.

Putra, I. N. W. A. (2010), Manajemen Laba: Perilaku Manajemen Opportunistic Atau Realistic, Retrieved from http://ejournal.unud.ac.id/abstrak/wijana\%20final.pdf.

Putra, R. (2012). Tradisi Hermeneutika dan Penerapannya dalam Studi Komunikasi. Ultimacomm, 4(1). https://doi.org/10.31937/ultimacomm.v4i1.431.

Riduwan, A. (2010). Etika dan Perilaku Koruptif dalam Praktik Manajemen Laba: Studi Hermeneutika. Jurnal Akuntansi dan Auditing Indonesia (JAAI), 14(2), 1410-2420. https://journal.uii.ac.id/JAAI/article/view/2250/2052.

Riduwan, A. (2012). Realitas dalam Cermin Retak: Laba Akuntansi dalam Bingkai Penafsiran Praktisi Bisnis Non-Akuntan. Jurnal Ekonomi dan Keuangan, 16(2). https://doi.org/ 10.24034/j25485024.y2012.v16.i2.2302.

Schipper, K. (1989). Commentary on Earnings Management. Accounting Horizon, 3, 91-102.

Schroeder, R. G., \& Clark., M. V. (1998). Accounting Theory: Text and Reading. New York: John Wiley \& Sons. 
Scott, W. R. (2000). Financial Accounting Theory. New Jersey: Prentice Hall Inc.

Setiawati, L., \& Na'im, A. (2000). Manajemen Laba. Jurnal of Indonesian Economy and Business, 15(4), 424-441. https://journal.ugm.ac.id/jieb/article/view/39145.

Neifar, S., Halioui K., \& Abdelaziz, F. B. (2016) The motivations of earnings management and financial aggressiveness in American firms listed on the NASDAQ 100, Journal of Applied Accounting Research, 17(4), 397-420. https://doi.org/10.1108/JAAR-05-2014-0051.

Subramanyam, K. R., \& Wild, J. J. (2009). Financial Statement Analysis. New York: McGraw-Hill.

Teoh, S. H., Welch, I., \& Wong, T. J. (1998). Earnings Management and The Underperformance of Seasoned Equity Offerings. Journal of Financial Economics, 50, 63-99.

Wang. (1994). Accounting Income Smoothing and Stockholder Wealth. Journal of Applied Bussines Research, 10(3), 96-104. http://dx.doi.org/10.19030/jabr.v10i3.5929.

Watts, R. L., \& Zimmerman, J. L. (1986). Positive Accounting Theory. New Jersey: Prentice Hall.

*) Murniati, Department of Islamic Communication and Broadcasting, University of Islam Nahdlatul Ulama, Jepara, Indonesia (Email: murniati@ unisnu.ac.id)

**) Mahmudatus Sa'diyah, Department of Islamic Economy, University of Islam Nahdlatul Ulama, Jepara, Indonesia (Email: mahdah@ unisnu.ac.id)

***) Subadriyah, Department of Accounting, University of Islam Nahdlatul Ulama, Jepara, Indonesia (Email: subadriyah @unisnu.ac.id) 